\title{
Beta Adrenoceptor Polymorphism and Clinical Response to Sertraline in Major Depressive Patients
}

\author{
Negar Firouzabadi ${ }^{1,4,5}$, Roshanak Raeesi ${ }^{2}$, Kamiar Zomorrodian $^{3}$, Ehsan Bahramali ${ }^{4}$, Ilnaz Yavarian² \\ ${ }^{1}$.Department of Pharmacology \& Toxicology, School of Pharmacy, Shiraz University of Medical Sciences, Shiraz, Iran. \\ 2.Department of Pharmacology, School of Pharmacy, Shiraz University of Medical Sciences, International Branch, Shiraz, \\ Iran. ${ }^{3}$ Department of Medical Parasitology and Mycology, School of Medicine, Shiraz University of Medical Sciences, \\ Shiraz, Iran. ${ }^{4}$ Non communicable Diseases Research Center, Fasa University of Medical Sciences, Fasa, Iran. ${ }^{5}$ Yasuj \\ University of Medical Sciences, Yasuj, Iran.
}

Received, October 31, 2016; Revised, December 2, 2016; Accepted, January 11, 2017; Published, January 11, 2017.

\begin{abstract}
Purpose: The adrenoceptor family, as one of the main contributors in regulating the noradrenergic system, has been studied in involvement of depression and its treatment. A functional polymorphism of G1165C on beta adrenoceptor ( $\beta \mathrm{AR}$ ) enhances post receptor signalling and is assumed to be involved in pharmacotherapy of depression. The aim of the present study was to discern the influence of G1165C polymorphism in the $\beta 1 \mathrm{AR}$ gene on individual differences in response to sertraline. Methods: One hundred newly diagnosed patients completed 6 weeks of sertraline treatment. Response to treatment was defined as a $50 \%$ decrease in Hamilton Rating Scale for depression (HRSD). Results: The patients who carried CC genotype responded five times more to sertraline comparing with other variants $(\mathrm{P}=0.005 ; \mathrm{OR}=5.7 ; 95 \% \mathrm{CI}=1.4-23.9)$. Moreover, carriers of $\mathrm{C}$ allele responded three times more to sertraline than patients with the $\mathrm{G}$ allele $(\mathrm{P}=0.001 ; \mathrm{OR}=3.3 ; 95 \% \mathrm{CI}=1.72-6.50)$. Conclusion: In conclusion, our results support the hypothesis that genetic variation of $\beta 1 \mathrm{AR}$ might influence clinical response to sertraline.
\end{abstract}

This article is open to POST-PUBLICATION REVIEW. Registered readers (see "For Readers") may comment by clicking on ABSTRACT on the issue's contents page.

\section{INTRODUCTION}

Major depressive disorder (MDD) being a common illness is assumed to be moderately inherited (1).The heritability of MDD is estimated to be about $31-42 \%$ $(2,3)$. A significant association between excess mortality and depression has been reported in various samples $(4,5)$. It has long been theorized that monoamines as neurotransmitters are involved in the pathogenesis of mental disorders such as depression $(6,7)$. Monoamine theory implies that depression is due to changes of brain monoaminergic activity and that antidepressants alter this activity $(8,9)$. Considerable clinical evidence support the crucial role of norepinephrine (NE) and serotonin in etiology of MDD (10-12). It is crystal clear that antidepressants eventually increase the synaptic concentration of these monoamines resulting in long-term adaptive changes (7). The central noradrenergic system, anatomically based in the locus coeruleus (LC) of brain stem, is responsible for noradrenergic neurotransmission in the brain and plays a pivotal role in cognitive processes
(13). The actions of NE are mediated by the family of $\mathrm{G}$ protein-coupled receptors (GPCRs) known as the adrenoceptors (ARs) (14).

Antidepressants can target almost all components of the monoaminergic system to induce their pharmacological actions $(15,16)$. Most genetic studies have considered set of functional polymorphisms relevant to monoaminergic neurotransmissionin depression (17-19). The ARs, consisting of $\beta, \alpha_{1}$, and $\alpha_{2}$ receptors, are the cellular mediators of noradrenergic neurotransmission. The $\beta A R s$ are classified in three groups of $\beta 1, \beta 2$ and $\beta 3$. The most frequent subtype in mammalian brain is $\beta 1$ which controls physiological responses to catecholamines. $\beta_{1} \mathrm{AR}$ was mapped on chromosome 10q24-q26. Studies have manifested a relationship between this region and depressive disorders $(20,21)$. All $\beta$

\footnotetext{
Corresponding Author: Negar Firouzabadi PhD, Department of Pharmacology \& Toxicology, School of Pharmacy, Shiraz University of Medical Sciences, Shiraz, Iran; E-mail: Firouzabadi@sums.ac.ir, nfirouzabadi@yahoo.com
} 
receptor subtypes couple to the stimulatory Gprotein (Gs) therefore activate the cyclic adenosine monophosphate (cAMP) signalling. Regarding the association between upregulation of $\beta A R s$ and depression it may be concluded that some classes of antidepressants such as selective serotonin reuptake inhibitors (SSRIs) may downregulate and desensitize these receptors in brain $(22,23)$. The functional polymorphism, G1165C, causing an amino acid variation Gly389Arg in the $\beta A R$ gene was recently identified. Several lines of study suggest that $C$ allele of this polymorphism may enhance coupling to the Gs protein and thereafter increase adenylyl cyclase activation $(24,25)$.

The pharmacological treatment of depression has been the centre of attention for many years. Although pharmacotherapy has alleviated morbidity of individuals with depression, only $30-40 \%$ of patients seem to respond completely to treatment (26). Among the antidepressants, the SSRIs are common first line treatments, especially due to their minimal adverse effects and good tolerability (27). It is believed that they are effective in brain adrenergic function as well which corroborate their non-serotonin dependant mechanism as a therapeutic option for $\operatorname{MDD}(28,29)$.

To the best of our knowledge, the association between $\beta A R s$ polymorphisms and response to sertraline has not yet been studied. Inter-individual variations in response to different SSRIs lead us to the hypothesis that therapeutic outcome might be partly influenced by genetics of $\beta$ ARs. Therefore we investigated, for the first time, the association between $\mathrm{G} 1165 \mathrm{C}$ polymorphism and sertraline treatment outcome in a population of depressed patients.

\section{METHODS}

\section{Study population}

This study was carried out in accordance with The Code of Ethics of the World Medical Association (Declaration of Helsinki) and Uniform Requirements for manuscripts submitted to biomedical journals. This work study was approved by the local committee for ethics of medical experiments on human subjects of Shiraz University of Medical Sciences. We obtained written consent from all participants prior to the interview. All patients were unrelated, of Caucasian origin and from the same geographical area.

Patients were recruited between 2011 and 2012 in Hafez hospital, Shiraz University of Medical
Sciences and followed during 6 weeks by an experienced psychiatrist. A total of 100 newly diagnosed MDD patients (male: 25, female: 75, mean age \pm S.D.: $35.5 \pm 12.9$ ) according to DSM V criteria were included in the study. Newly diagnosed was defined as a negative previous diagnosis of depression and no history of antidepressant medications use. An initial 21-item Hamilton Depression Rating Scale (HDRS) was used to evaluate the severity of depression (30). Exclusion criteria were as follows: anxiety disorders, a family history of schizophrenia, a personal history of bipolar disorder, a family history of bipolar disorder in first-degree relatives; a personal history of schizophrenia, manic or hypomanic episode, mood incongruent psychotic symptoms, active substance dependence, and current treatment with antipsychotics or mood stabilizers.

\section{Drug administration}

Sertraline $\quad\left(\right.$ SERTRALINE-ABIDI ${ }^{\circledR}$ ) was administered at a fixed-dose regimen of $50 \mathrm{mg}$ for one week initially. The dose could be increased by $50 \mathrm{mg} /$ day per week to a maximum of $200 \mathrm{mg} /$ day according to clinical response over the 6 week treatment duration. Only hypnotics such as zolpidem or anxiolytics such as chlordiazepoxide were allowed for severe anxiety. A positive clinical response to sertraline treatment was considered if at least $50 \%$ reduction in the baseline HDRS score was observed through the sixth week. Evaluations were done at baseline, weeks 1 and 6 of treatment. Prior to interviewing, $5 \mathrm{ml}$ of venous blood samples were collected for further genotyping

\section{DNA extraction and genotype determination}

DNAs were extracted from leukocytes of whole blood using a salting out method (31). PCR amplification of $\mathrm{G} 1165 \mathrm{C}$ was performed using primers mentioned in Table 1. Genotyping of G1165C was done as described previously by Moriyama et al. (32). An Eppendorf gradient Master cycler (Hamburg, Germany) PCR machine was used as the thermal cycler. PCR products $(7 \mu 1)$ were digested with Mva I (TaKaRaBio). Electrophoresis on $3 \%$ agarose (Invitrogen ${ }^{\circledR}$ Ultra Pure) gel was used to separate digested fragments. They were then stained by ethidium bromide and visualized in a UV trans illuminator. It is to mention that all of the samples were genotyped at least twice and reconfirmed. 


\section{STATISTICS}

SPSS ${ }^{\circledR} 21.0$ for windows ${ }^{\circledR}$ was used for data analysis (SPSS Inc., Chicago, Illinois). HardyWeinberg equilibrium (HWE) for distribution of genotypes was calculated by chi-square $\left(\chi^{2}\right)$ test. Continuous variables are revealed as mean \pm S.D. Genotype frequencies are presented in percentage (\%). Kolmogorov-Smirnov test was used to test the normal distribution of continuous variables. Associations between categorical variables were calculated by Pearson's chi-square or Fisher's exact test and for interval data by Student's t-test. $\chi^{2}$ test was performed for univariate analysis of genotypes. Odds ratio (OR) and $95 \%$ confidence intervals (CI) were calculated. $\mathrm{P}$ value $<0.05$ was considered as statistically significant.

\section{RESULTS}

In terms of response, 33 patients (33\%), were responders to sertraline (baseline HDRS: $26.1 \pm 10.2$; HDRS after week 6: $11.1 \pm 7.5)$ and 67 patients (67\%), were non-responders (baseline HDRS: 26.3 \pm 9.5 ; HDRS after week 6: 21.9 \pm 9.5 ). Demographic data of patients are demonstrated in Table 2. Table 3 shows genotype and allele frequencies of patients receiving sertraline based on
$50 \%$ score reduction. Patients carrying CC genotype responded significantly more to sertraline than patients carrying either GG or GC genotypes $(\mathrm{P}=0.005 ; \mathrm{OR}=5.7 ; 95 \% \mathrm{CI}=1.4-23.9)$. Moreover, carriers of $\mathrm{C}$ allele responded by 3.3 fold better to sertraline than carriers of $\mathrm{G}$ allele $(\mathrm{P}=0.001$; $\mathrm{OR}=$ $3.3 ; 95 \% \mathrm{CI}=1.72-6.50)$.

\section{DISCUSSION}

As to our knowledge, this is the first study examining the association of G1165C polymorphism on $\beta_{1} \mathrm{ARs}$ gene and response to sertraline in a population of newly diagnosed Iranian MDD patients. The inspiration of the present study was the significant role of $\beta$ ARs in neural and autonomic functions (33, 34 ) and the important contribution of genetics on the outcome of antidepressant pharmacotherapies(26, $35)$.

The novel findings of our study is the significant association of CC genotype of $\mathrm{G} 1165 \mathrm{C}$ with response to sertraline. Patients carrying the $\mathrm{CC}$ genotype responded 5.7 fold more to sertraline comparing to carriers of other variants $(\mathrm{P}=0.005$, $\mathrm{OR}=5.7 ; 95 \% \mathrm{CI}=1.4-23.9)$. Also carriers of the $\mathrm{C}$ allele represented 3.3 fold better response to sertraline comparing with other variants $(\mathrm{P}=0.001$, $\mathrm{OR}=3.3 ; 95 \% \mathrm{CI}=1.72-6.50)$.

Table 1. Primers, PCR condition and locations of $\beta 1 \mathrm{AR}$, G1165C polymorphism on DNA.

\begin{tabular}{|c|c|c|c|c|c|c|}
\hline $\begin{array}{l}\text { Polymor } \\
\text { phisms }\end{array}$ & Primer sequence $\left(5^{\prime}-3^{\prime}\right)$ & Location & Restriction enzyme & Allele & $\begin{array}{l}\text { DNA fragment size } \\
\text { (bp) }\end{array}$ & References \\
\hline $\begin{array}{l}\text { G1165C } \\
(\beta 1 A R)\end{array}$ & $\begin{array}{l}\text { F- } \\
\text { ACGCTGGGCATCA } \\
\text { TCATGGGC } \\
\text { R- } \\
\text { ACATCGTCGTCGT } \\
\text { CGTCGTCC }\end{array}$ & $\begin{array}{l}\text { chromosome } \\
(10 \mathrm{q} 25.3)\end{array}$ & MvaI at $37^{0 \mathrm{C}} / 16 \mathrm{hrs}$ & $\begin{array}{l}\mathrm{G} \\
\mathrm{C}\end{array}$ & $\begin{array}{l}280 / 52 \\
142 / 138 / 52\end{array}$ & $\begin{array}{l}\text { (Zill et } \\
\text { al., 2003) }\end{array}$ \\
\hline
\end{tabular}

PCR: Polymerase Chain Reaction; $\beta 1 A R$ : Adrenergic beta receptor 1, F: Forward primer, R: Reverse primer.

Table 2. Demographic characteristics of patients responsive to sertraline.

\begin{tabular}{llll}
\hline $\begin{array}{l}\text { Variables } \\
\text { Sex (male/female) }\end{array}$ & Responders ( $\mathrm{n}=33)$ & $\begin{array}{l}\text { Non-responders }(\mathrm{n}=67) \\
16 / 51\end{array}$ & $\begin{array}{l}\text { P-value } \\
0.713\end{array}$ \\
\hline Age (years) & & & \\
HAMD score 1 (before treatment) & $35.2 \pm 13.7$ & $35.4 \pm 12.5$ & 0.936 \\
HAMD score 2 (after treatment) & $26.1 \pm 10.2$ & $26.3 \pm 9.5$ & 0.911 \\
\hline
\end{tabular}


Table 3. Genotype and allele frequencies of G1165C variant in patients receiving sertraline.

\begin{tabular}{llllll}
\hline Polymorphism & Genotype & \multicolumn{1}{l}{ Responders $(\mathrm{n}=33)$} & Non-responders $(\mathrm{n}=67)$ & $P_{C}$ & OR; 95\% CI \\
\hline Genotypes & & & & 0.003 & $5.7 ; 1.4-23.9$ \\
& $\mathrm{GG}$ & 13 & 46 & & \\
& $\mathrm{GC}$ & $(39.4 \%)$ & $(68.6 \%)$ & & \\
& & $(36.4 \%)$ & 18 & & \\
& $\mathrm{CC}$ & 8 & $(26.9 \%)$ & & \\
& & $(24.2 \%)$ & $(4.5 \%)$ & & \\
Alleles & $\mathrm{G}$ & $38(57.6 \%)$ & $111(82.8 \%)$ & $3.3 ; 1.72-6.50$ \\
& $\mathrm{C}$ & $28(42.4 \%)$ & $23(17.2 \%)$ & \\
& $\mathrm{C}$ & & \\
\hline$P_{C}:$ P-value for $\chi^{2}$ test, OR: Odds Ratio, CI: Confidence interval & \\
\hline
\end{tabular}

While world-wide rate of depression is rapidly increasing(36), response to antidepressants and remission is fairly satisfactory (37). Although many studies bold the contribution of genetics in predisposition to MDD, its role as therapeutic determinant remains obscure.

$\beta_{1}$ ARsbelong to the family of GPCRs representing the leading target for modern drug therapy (38). GPCRs is a foremost contributor to the pathophysiology of several mental illnesses $(39,40)$ . Several lines of evidence have proven the consistent and significant role of adrenergic system in affective disorders. Between components of beta adrenergic system, $\beta_{1}$ ARs have been broadly studied and seem to have major contribution in the pathophysiology of depression(41, 42). Chronic treatment with most antidepressant drugs leads to down regulation and desensitization of $\beta_{1}$ ARs in particular regions of brain especially the hippocampus, and not the $\beta_{2}$ ARs. Pharmacological effect of antidepressants showing 10 -30 more affinity for $\beta_{1}$ receptors than $\beta_{2}$ is a good justification for this finding (43-45).

Biochemical, anatomical and electrophysiological data indicate a reciprocal interaction between the serotonergic and adrenergic systems (46). This may explain why intact serotonergic system is essential for pharmacologic actions of tricyclic antidepressants as well (47). On the other hand administration of sertraline resulted in reduction in number of beta adrenoceptors in rat (46) which suggests an effective interaction of sertraline with these receptors. The interplay of adrenoceptor and serotonergic systems in the brain, aside from the effects of SSRIs on the reuptake of norepinephrine, is further described by the role of cathecholamines in the pathophysiology of depression (48) where the effects of major anti-depressant medications can be echoed in those with augmented adrenergic responses. Together with the abundance of norepinephrine (secondary to its reuptake inhibition) and the downregulation of adrenoceptors by sertraline, certain polymorphisms of adrenoceptor gene, G1165C in this study, is shown to be effective in therapeutic response in sertraline users.

The $\beta_{1} A R$ gene is located in $10-24 q-26$ region (49) and the functional common polymorphism happens in $\mathrm{G} 1165 \mathrm{C}$ nucleotide that induces an amino acid substitution from glycine to arginine at position $389 \beta_{1} \mathrm{AR}$, the region that located in fourth intracellular loop of receptor and is very important for the coupling to $G_{s}$. In other words presence of $C$ allele enhances the coupling of $\mathrm{G}_{\mathrm{s}}$ and consequently increases the level of cAMP and signal transduction. Signal transduction cascade has very important role in implement of drug effect. The $\mathrm{C}$ allele by inducing signal transduction and second messenger activity leads to vast transcription factors level. As a consequence elevated transcription factors regulate gene expression that cause down or up regulation of the number and sensitivity of receptors or amount of inhibitory or stimulatory $G$ proteins by feedback mechanisms and therefore is responsible for more adaptive drug responses (24). All together may explain our finding that carriers of the $\mathrm{C}$ allele responded better to treatment than carriers of the $G$ allele.

A study conducted by Crowley et al., showed lack of association between the investigated functional polymorphism (G1165C) and response to citalopram in depressed patients although the region containing this variant strongly influenced response 
to citalopram in a mouse model of depression. It is to note that in the mentioned study, ethnic differences was detected in genotype and allele frequencies (50). On the other hand, as reported previously by Zill et al this variant is not associated with either MDD nor antidepressant response but the $\mathrm{C}$ allele might be an indicator for a more rapid and maybe even better response to antidepressant medication (25). It is worthy of mentioning that different categories of antidepressants were used in the study conducted by Zill et al, and not a certain drug, but our study was restricted to examining the effect of genetic variations on response to an SSRI like sertraline. Thus, these studies may boost the assumption about the role of $\mathrm{G} 1165 \mathrm{C}$ polymorphism in antidepressant outcome.

Recruiting solely the newly diagnosed MDD patients with two conditions: the absence of concomitant psychiatric disorders and parallel medication use; may approximate a cause and effect relationship in our results. Keeping the major confounders at a minimum level, our observational study could well demonstrate the relation of a better response rate to sertraline with carrying the $\mathrm{C}$ allele of $\beta_{1} \mathrm{AR}$ gene. To provide stronger evidence to support our findings, we recommend the conduct of a randomized controlled trial of sertraline versus placebo in $\mathrm{G}$ and $\mathrm{C}$ allele carriers. Besides regarding conflicting reports suggesting diverse responses to therapy in $\mathrm{C}$ allele carriers in different populations, replication studies are warranted.

It would be worth mentioning that involvement of genetics in pharmacotherapy is a part of several mechanisms leading to different treatment outcome. Depression and other multifactorial affective disorders are more complex than could be interpreted by only one mechanism and $\beta_{1} A R$ variants may have a minor role in response to treatment.

\section{CONCLUSION}

Our result suggests that functional genetic variant in $\beta$ ARs would be a predictor for response to sertraline. However; further investigations about different variants of ARs may provide more promising data for individualized therapy in depression.

\section{REFERENCES}

1. Flint J, Kendler KS. The genetics of major depression. Neuron. 2014;81(3):484-503. doi: 10.1016
2. Kendler KS, Gatz M, Gardner CO, Pedersen NL. A Swedish national twin study of lifetime major depression. American Journal of Psychiatry. 2006;163(1):109-14. doi: 10.1176/appi.ajp.163.1.109

3. Sullivan PF, Neale MC, Kendler KS. Genetic epidemiology of major depression: review and meta-analysis. American Journal of Psychiatry. 2014;157(10):1552-62.

doi:10.1176/appi.ajp.157.10.1552

4. Kanser ÇH. Depression and Risk of Stroke Morbidity and Mortality. Jama. 2011;306(11):1241-9. doi: 10.1001/jama.2011.1282.

5. Barth J, Schumacher M, Herrmann-Lingen C. Depression as a risk factor for mortality in patients with coronary heart disease: a metaanalysis. Psychosomatic medicine. 2004;66(6):802-13. doi: 10.1097/01.psy.0000146332.53619.b2

6. Hirschfeld RM. History and evolution of the monoamine hypothesis of depression. The Journal of clinical psychiatry. 2000;61(suppl 6):4-6.

7. Elhwuegi AS. Central monoamines and their role in major depression. Progress in NeuroPsychopharmacology and Biological Psychiatry. 2004;28(3):435-51. doi: 10.1016/j.pnpbp.2003.11.018

8. Schildkraut JJ. The catecholamine hypothesis of affective disorders: a review of supporting evidence. American Journal of Psychiatry. 1965;122(5):509-22. doi: 10.1176/ajp.122.5.509

9. Krishnan V, Nestler EJ. The molecular neurobiology of depression. Nature. 2008;455(7215):894-902. doi: 10.1038 /nature 07455 .

10. Delgado PL, Moreno FA. Role of norepinephrine in depression. The Journal of clinical psychiatry. 2000;61(suppl 1):5-12.

11. Amsterdam JD, Newberg AB, Newman CF, Shults J, Wintering N, Soeller I. Change Over Time in Brain Serotonin Transporter Binding in Major Depression: Effects of Therapy Measured with [123I]-ADAM SPECT. Journal of Neuroimaging. 2013;23(4):469-76. doi: 10.1111/jon.12035.

12. Cai X, Kallarackal AJ, Kvarta MD, Goluskin S, Gaylor K, Bailey AM, et al. Local potentiation of excitatory synapses by serotonin and its alteration in rodent models of depression. Nature neuroscience. 2013;16(4):464-72. doi: $10.1038 / \mathrm{nn} .3355$

13. Sara SJ. The locus coeruleus and noradrenergic modulation of cognition. Nature reviews neuroscience. 2009;10(3):211-23. doi: $10.1038 / \mathrm{nrn} 2573$. 
14. Gautam N, Downes G, Yan K, Kisselev O. The G-protein $\beta \gamma$ complex. Cellular signalling. $1998 ; 10(7): 447-55 . \quad$ doi.10.1016/S08986568(98)00006-0

15. Cottingham C, Wang Q. $\alpha 2$ adrenergic receptor dysregulation in depressive disorders: Implications for the neurobiology of depression and antidepressant therapy. Neuroscience \& Biobehavioral Reviews. 2012;36(10):2214-25. doi: 10.1016/j.neubiorev.2012.07.011.

16. Willner P, Scheel-Krüger J, Belzung C. The neurobiology of depression and antidepressant action. Neuroscience \& Biobehavioral Reviews. 2013;37(10):2331-71. doi: 10.1016/j.neubiorev.2012.12.007.

17. Phillips JL, Batten LA, Tremblay P, Aldosary F, $\mathrm{Du} \mathrm{L}$, Blier P. Impact of monoamine-related gene polymorphisms on hippocampal volume in treatment-resistant depression. Acta Neuropsychiatrica. 2015;27(06):353-61. doi: 10.1017/neu.2015.25.

18. Gao Z, Yuan H, Sun M, Wang Z, He Y, Liu D. The association of serotonin transporter gene polymorphism and geriatric depression: A metaanalysis. Neuroscience letters. 2014;578:148-52. doi: 10.1016/j.neulet.2014.06.046.

19. Pan Y, Cheng Q, Shan M-S, Yan J. Association between polymorphism of the norepinephrine transporter gene rs2242446 and rs5669 loci and depression disorders. International journal of clinical and experimental medicine. 2015;8(10):18837.

20. Yang-Feng TL, Xue F, Zhong W, Cotecchia S, Frielle T, Caron $\mathrm{MG}$, et al. Chromosomal organization of adrenergic receptor genes. Proceedings of the National Academy of Sciences. 1990;87(4):1516-20.

21. Burcescu I, Wigg K, Gomez L, King N, Vetro A, Kiss E, et al. Association study of the adrenergic receptors and childhood-onset mood disorders in Hungarian families. American Journal of Medical Genetics Part B: Neuropsychiatric Genetics. 2006;141(3):227-33. doi: 10.1002/ajmg.b.30292

22. Sanders-Bush E, Breeding M, Knoth K, Tsutsumi M. Sertraline-induced desensitization of the serotonin 5HT-2 receptor transmembrane signaling system. Psychopharmacology. 1989;99(1):64-9. doi: 10.1007/bf00634454

23. Rivero G, Gabilondo AM, García-Sevilla JA, La Harpe R, Callado LF, Meana JJ. Increased $\alpha$ 2and $\beta 1$-adrenoceptor densities in postmortem brain of subjects with depression: differential effect of antidepressant treatment. Journal of affective disorders. 2014;167:343-50. doi: 10.1016/j.jad.2014.06.016.

24. Mason DA, Moore JD, Green SA, Liggett SB. A gain-of-function polymorphism in a G-protein coupling domain of the human $\beta 1$-adrenergic receptor. Journal of Biological Chemistry. $1999 ; 274(18): 12670-4$. 10.1074/jbc. 274.18 .12670

25. Zill P, Baghai TC, Engel R, Zwanzger P, Schüle $\mathrm{C}$, Minov C, et al. Beta-1-adrenergic receptor gene in major depression: Influence on antidepressant treatment response. American Journal of Medical Genetics Part B: Neuropsychiatric Genetics. 2003;120(1):85-9. doi: 10.1002/ajmg.b.20017

26. Serretti A, Artioli P, Quartesan R. Pharmacogenetics in the treatment of depression: pharmacodynamic studies. Pharmacogenetics and genomics. 2005;15(2):61-7. doi: 10.1097/01213011-200502000-00001

27. Rush AJ, Trivedi MH, Wisniewski SR, Stewart JW, Nierenberg AA, Thase ME, et al. Bupropion-SR, sertraline, or venlafaxine-XR after failure of SSRIs for depression. New England Journal of Medicine. 2006;354(12):1231-42. 10.1056/NEJMoa052963

doi:

28. Gobert A, Rivet JM, Cistarelli L, Melon C, Millan M. $\alpha 2$-Adrenergic Receptor Blockade Markedly Potentiates Duloxetine-and Fluoxetine-Induced Increases in Noradrenaline, Dopamine, and Serotonin Levels in the Frontal Cortex of Freely Moving Rats. Journal of neurochemistry. 1997;69(6):2616-9. doi: 10.1046/j.1471-4159.1997.69062616.x

29. Cryan JF, O'Leary OF, Jin S-H, Friedland JC, Ouyang M, Hirsch BR, et al. Norepinephrinedeficient mice lack responses to antidepressant drugs, including selective serotonin reuptake inhibitors. Proceedings of the National Academy of Sciences of the United States of America. 2004;101(21):8186-91. doi: 10.1073/pnas.0401080101

30. Hamilton M. A rating scale for depression. Journal of neurology, neurosurgery, and psychiatry. 1960;23(1):56. doi: 10.1136/jnnp.23.1.56

31. Miller S, Dykes D, Polesky H. A simple salting out procedure for extracting DNA from human nucleated cells. Nucleic acids research. 1988;16(3):1215. doi: 10.1093/nar/16.3.1215

32. Moriyama A, Nishizawa D, Kasai S, Hasegawa J, Fukuda K-i, Nagashima M, et al. Association Between Genetic Polymorphisms of the $\beta 1$ Adrenergic Receptor and Sensitivity to Pain and Fentanyl in Patients Undergoing Painful Cosmetic Surgery. Journal of pharmacological sciences. 2013;121(1):48-57. doi: 10.1254/jphs.12159FP

33. Grassi G, Seravalle G, Dell'Oro R, Turri C, Bolla GB, Mancia G. Adrenergic and reflex 
abnormalities in obesity-related hypertension. Hypertension. 2000;36(4):538-42. doi: 10.1161/01.HYP.36.4.538

34. Ramos BP, Arnsten AF. Adrenergic pharmacology and cognition: focus on the prefrontal cortex. Pharmacology \& therapeutics. 2007;113(3):523-36. doi: 10.1016/j.pharmthera.2006.11.006

35. Schosser A, Kasper S. The role of pharmacogenetics in the treatment of depression and anxiety disorders. International clinical psychopharmacology. 2009;24(6):277-88. doi: 10.1097/YIC.0b013e3283306a2f

36. Marcus M, Yasamy MT, van Ommeren M, Chisholm D, Saxena S. Depression: A global public health concern. WHO Department of Mental Health and Substance Abuse. 2012;1:68. doi: 10.1037/e517532013-004

37. Machado M, Iskedjian M, Ruiz I, Einarson TR. Remission, dropouts, and adverse drug reaction rates in major depressive disorder: A metaanalysis of head-to-head trials. Current Medical Research and Opinion. 2006;22(9):1825-37. doi: 10.1185/030079906X132415

38. Whalen EJ, Foster MW, Matsumoto A, Ozawa $\mathrm{K}$, Violin JD, Que LG, et al. Regulation of $\beta$ Adrenergic Receptor Signaling by SNitrosylation of G-Protein-Coupled Receptor Kinase 2. Cell. 2007;129(3):511-22. doi: 10.1016/j.cell.2007.02.046

39. Arnsten AF. Adrenergic targets for the treatment of cognitive deficits in schizophrenia. Psychopharmacology. 2004;174(1):25-31. doi: 10.1007/s00213-003-1724-3

40. Catapano LA, Manji HK. G protein-coupled receptors in major psychiatric disorders. Biochimica et Biophysica Acta (BBA)Biomembranes. 2007;1768(4):976-93. doi: 10.1016/j.bbamem.2006.09.025

41. Crissman AM, Makhay MM, O'Donnell JM. Discriminative stimulus effects of centrally administered isoproterenol in rats: mediation by beta-1 adrenergic receptors. Psychopharmacology. 2001;154(1):70-5. doi: $10.1007 / \mathrm{s} 002130000618$

42. Manji HK, Lenox RH. Signaling: cellular insights into the pathophysiology of bipolar disorder. Biological psychiatry. 2000;48(6):51830. doi: 10.1016/S0006-3223(00)00929-X
43. Kirigiti P, Yang Y-f, Li X, Li B, Midson CN, Machida CA. Rat $\beta 1$-adrenergic receptor regulatory region containing consensus AP-2 elements recognizes novel transactivator proteins. Molecular Cell Biology Research Communications. 2000;3(3):181-92. doi: 10.1006/mcbr.2000.0212

44. Koe BK, Koch SW, Lebel LA, Minor KW, Page MG. Sertraline, a selective inhibitor of serotonin uptake, induces subsensitivity of $\beta$-adrenoceptor system of rat brain. European Journal of Pharmacology. 1987;141(2):187-94. doi: 10.1016/0014-2999(87)90262-7

45. Sulser F. Antidepressant treatments and regulation of norepinephrine-receptor-coupled adenylate cyclase systems in brain. Advances in biochemical psychopharmacology. 1983;39:249-61.

46. Byerley WF, McConnel EJ, McCabe RT, Dawson TM, Grosser BI, Wamsley JK. Chronic administration of sertraline, a selective serotonin uptake inhibitor, decreased the density of $\beta$ adrenergic receptors in rat frontoparietal cortex. Brain research. 1987;421(1):377-81. doi: 10.1016/0006-8993(87)91312-6

47. Dumbrille-Ross A, Tang SW. Noradrenergic and serotonergic input necessary for imipramineinduced changes in beta but not $\mathrm{S} 2$ receptor densities. Psychiatry research. 1983;9(3):207-15. doi: 10.1016/0165-1781(83)90045-8

48. Eriksson E. Antidepressant drugs: does it matter if they inhibit the reuptake of noradrenaline or serotonin? Acta Psychiatrica Scandinavica. 2000;101(s402):12-7. doi: 10.1034/j.16000447.2000.00003.x

49. Maqbool A, Hall A, Ball S, Balmforth A. Common polymorphisms of $\beta$ 1-adrenoceptor: identification and rapid screening assay. The Lancet. 1999;353(9156):897. doi: 10.1016/s0140-6736(99)00549-8

50. Crowley JJ, Lipsky RH, Lucki I, Berrettini WH. Variation in the genes encoding vesicular monoamine transporter 2 and beta- 1 adrenergic receptor and antidepressant treatment outcome. Psychiatric genetics. 2008;18(5):248-51. doi: 10.1097/ypg.0b013e3283052ff7 